\title{
A Report on the Hysteroscopic Removal of a Gräfenberg Ring After Almost Fifty Years in Utero
}

\author{
Ein unerwarteter intrauteriner Fremdkörper - \\ Entfernung eines Gräfenberg-Rings nach 50 Jahren Liegedauer
}

Authors

Affiliations
P. Baldauf ${ }^{1}$, R. Tönnes ${ }^{2}$, S. Simon ${ }^{3}$, M. David ${ }^{4}$

${ }^{1}$ Gynaecology, Vivantes Klinikum Am Urban, Berlin

2 Gynaecologist, Berlin

${ }^{3}$ Rathgen Research Laboratory, Berlin State Museum, Berlin

${ }^{4}$ Gynaecology Clinic, Charité Campus Virchow-Klinikum, Berlin
Key words

- gynaecology

- uterus

- contraception

Schlüsselwörter

- Gynäkologie

- Uterus

- Kontrazeption

Deutschsprachige Zusatzinformationen online abrufbar unter: www.thieme-connect.de/ ejournals/toc/gebfra

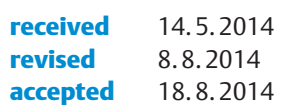

Bibliography

DOI http://dx.doi.org/

10.1055/s-0034-1383130

Geburtsh Frauenheilk 2014; 74 :

1023-1025 @ Georg Thieme

Verlag KG Stuttgart · New York · ISSN 0016-5751

\section{Correspondence}

Prof. Matthias David

Charité Campus

Virchow-Klinikum

Department of Gynaecology

Augustenburger Platz 1

13353 Berlin

matthias.david@charite.de

\section{Abstract}

$\nabla$

A report on the hysteroscopic removal of a Gräfenberg ring after almost fifty years in utero. In addition to the differential diagnostic considerations, the medical history aspects of this case are particularly interesting.

\section{Case Presentation}

A 67-year-old patient was admitted to the clinic following post-menopausal bleeding. Secondary findings consisted of COPD and non-insulin dependent diabetes mellitus type 2 . On examination, the vaginal sonogram found a hyper-dense structure a few millimetres thick in the uterine cavity, with otherwise inconspicuous internal genitals ( $\bullet$ Fig. 1 ). When asked, the patient reported that she has had a "gold spiral" in her uterus since approx. 1963. In the hysteroscopy, a slightly corroded metal spiral ( $\bullet$ Fig. 2 ) could be observed in the uterus, which could be removed completely and surprisingly problem-free given its almost 50 years retention in utero through a surgical hysteroscopy. A fractionated abrasion was then performed. The histological finding resulted in little endometrium without atypia or malignancy, no mucosal necrosis or pigment deposits - possibly metallosis.

The spiral was identified as a Gräfenberg ring and, based on the medical history, a micro X-ray fluorescence analysis was carried out in the Rathgen research laboratory of Berlin State Museum using an ArtTAX Pro device (formerly Röntec GmbH, now Bruker). It appeared that the Gräfenberg ring examined ( Fig. 3) consists of approx. 97\% silver and approx. $3 \%$ copper. The alloy corresponds to Britannia silver, a British silver standard (95.84\%).

\section{Zusammenfassung \\ $\nabla$}

Berichtet wird über die hysteroskopische Entfernung eines Gräfenberg-Rings nach fast 50 Jahren Liegedauer. Neben differenzialdiagnostischen Erwägungen sind besonders die medizinhistorischen Aspekte dieses Falls interessant.

\section{Discussion}

The unexpected discovery and removal of a Gräfenberg ring after approx. 50 years of retention gave rise to differential diagnostic considerations - in the event of a corresponding sonographic endometrial finding, a long-term or even "forgotten" intrauterine foreign body made of various materials, but in particular a metal IUD, must always be considered. Here, as it frequently is, a good medical history is helpful. In addition, this medical rarity allowed us to remember Ernst Gräfenberg (1881-1957) and his development, the Gräfenberg ring. Following his training at Kiel University Hospital for Women under Werth and Pfannenstiel, Ernst Gräfenberg moved to Berlin and set up a gynaecological practice in BerlinSchöneberg [19]. He later moved his thriving practice to a very central location in Kurfürstendamm. Here, he treated the wives of businessmen and diplomats, with his patients including famous women from the Berlin theatre and opera scene [2]. However, he wasn't simply a popular and prominent doctor, but was also rather socially involved. He first discussed "his" intrauterine spiral in December 1928 at a course on birth control held at the initiative of liberal doctors [11]. In addition, Gräfenberg was likely the head doctor at the sixty-bed gynaecological department at Berlin-Britz Hospital from 1930-1933 in addition to his work in his practice. In 1933, three chief doctors at the hospital, including Gräfenberg, were fired by the National Socialists due to their Jewish 


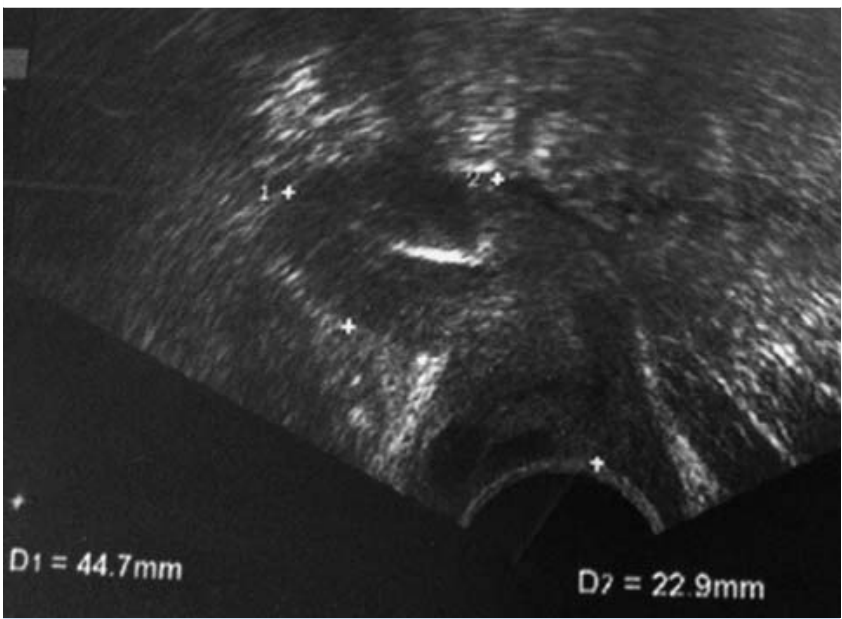

Fig. 1 Ultra-dense recording of the uterus with the Gräfenberg ring (hyper-dense structure in the uterus), uterus length $44.7 \mathrm{~mm}$ (D1), uterus a.-p. $22.9 \mathrm{~mm}$ (D2) (photo: P. Baldauf).

background. In 1937, Gräfenberg was even arrested and sentenced to many years in prison. After the disposal of all of his assets, a large fine was able to be paid and, with a larger security deposit from the founder of the global birth control movement, Margarete Sanger, in August 1940, the prerequisites for his release from Brandenburg prison and for Gräfenberg to leave for the USA were met [2]. For more detailed biographical data and more information about the sexual-medical discovery associated with his name, the $\mathrm{G}$ spot, we refer to the article by David and Ebert [3].

The discovery of a Gräfenberg ring in utero is a rarity nowadays. In the past 35 years, only three case studies have appeared in international literature: In 1980, Farghaly and Mathie reported about a ring found after 39 years which was discovered during a hysterectomy on a 71-year-old patient [7]; in 1985, an abrasion was carried out on a 52-year-old patient due to a bleeding disorder, which resulted in a Gräfenberg ring being removed after 20 years in utero [12]; a ring had to be removed from a 57-yearold patient 20 years after application due to complications [1]. At the end of the 19th century, there were pessaries in various forms made of a variety of materials, which differ from the ring later de-

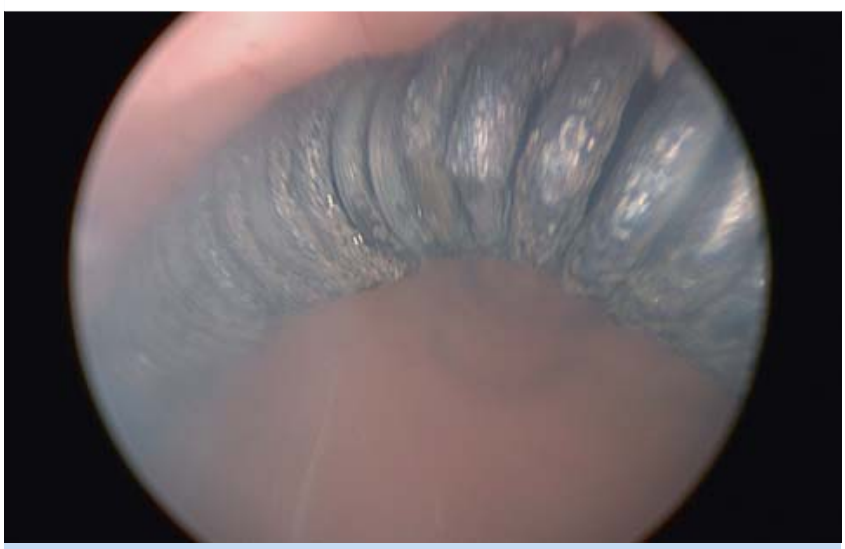

Fig. 2 Gräfenberg ring in utero (hysteroscopic recording) (photo: P. Baldauf). veloped by Gräfenberg in one key point: A so-called stem pessary also had a mostly rigid connection from the uterus to the vagina, meaning that ascending infections and serious complications could be the result. The Gräfenberg ring was entirely intrauterine, however. The method was relatively comfortable for the patient; the ring was able to be placed within a matter of minutes [13]. The Gräfenberg ring found is a predecessor to all modern intrauterine pessaries [6]. At the beginning of the 1920s, Ernst Gräfenberg began with the insertion of silk rings for the purposes of preventing pregnancy. Gräfenberg then wrapped these special silk thread rings in silver, before doing away with the silk altogether and moving towards only using small spiral-shaped silver wire rings (2-3 cm in diameter). In 1929, he described the duration of time his rings were to remain in utero:"[...] No damage is caused through the foreign body remaining in utero for external reasons for longer than one year. I have even observed a series of cases in which their silk ring was 'forgotten' and was only remembered after six or eight years later when found by chance." [11]. When Gräfenberg last discussed in detail the intrauterine contraception method he had developed in 1930 in Zurich, he reviewed 1100 of his own silk ring applications with a failure/pregnancy rate of $3.2 \%$, and approx. 600 silver ring inserts with a rate of $1.6 \%$ [20]. Jessen et al. [13] later reported a pregnancy rate of $2.3 \%$ (473/20768 women) in a compilation of various publications. In their publication, Wagner et al. [24] described the development phases up to the actual Gräfenberg pessary, whereby the spiral ring could be made of gold, silver or nickel silver. Gräfenberg evidently observed the lowest pregnancy rates with the silver ring as well as the fewest inflammatory reactions in histological examinations, which were conducted for him by the then gynaecological pathologist of Charité, Robert Meyer, and believed the cause to lie in the purity of the material [19]. Gräfenberg believed that the contraceptive effect of his rings was not caused by an inflammatory reaction or a mechanic irritation of the mucous membrane, but rather that the nidation of the blastocyst was prevented, i.e. there was a "pre-abortive effect" [11,20]. The copper content of the silver used probably also played a role [24]. According to Tatum, many Gräfenberg rings were made of nickel silver: an alloy that contains nickel, tin and up to 60\% copper [21]. In 1977, Wagner et al. reported on the analysis of a Gräfenberg ring that was removed from a woman following post-menopausal bleeding due to abrasion after spending 34 years in utero. Histologically speaking, the patient was found to have low grade hy-

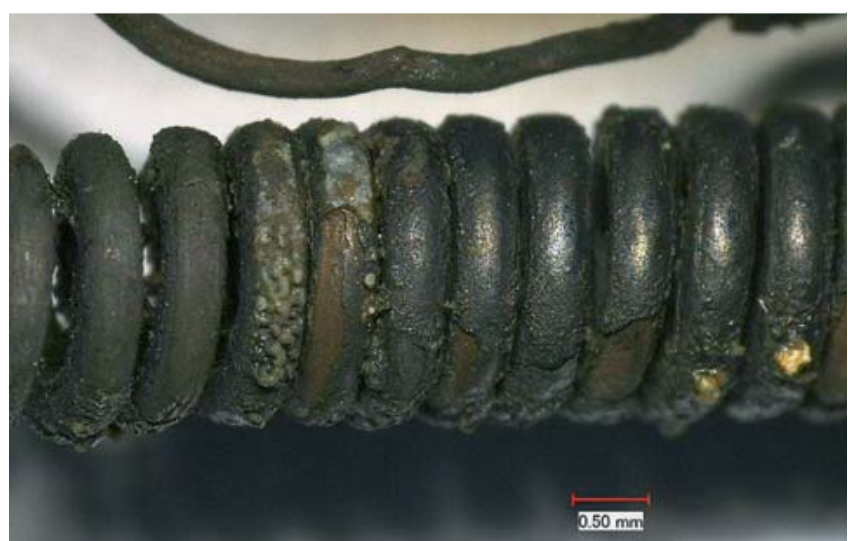

Fig. 3 The surface of the Gräfenberg ring ( $\times 50)$ (photo: Rathgen research lab). 
perplastic endometrium without inflammatory reactions. An $\mathrm{X}$-ray analysis was carried out to determine the material. The data suggests a silver ring with a low copper content, and therefore the technical or nickel silver mentioned above [24]. The silver and gold spirals applied intrauterinely by Gräfenberg to prevent pregnancy were also distributed internationally at the end of the 1920s [18].

In 1931, birth control was one of the primary topics at the conference of the German Gynaecology Society in 1931. This event was already largely characterised by German nationals. Gräfenberg therefore had a hard job as an advocate of birth control. In addition to almost unanimous professional rejection of his ring, he was also confronted with ethical and demographic arguments [14]. Not being a qualified gynaecologist and working outside the university, his words carried practically no weight. In his closing words, Conference President Fraenkel stated: “[...] Among the many disparaging judgements made about the Gräfenberg ring at the Zurich conference last year, Norman Haire, despite being the only fan of the procedure, Klein and Leunbach produced new material. [...] I have established that the conference has rejected all intrauterine methods" [8]. In line with the predominant sinister ideological and power relationships from 1933, the German Gynaecology Society passed a resolution in 1935, stating that “[...] the application of intrauterine prophylactics for the purposes of preventing pregnancy is dangerous and life-threatening [...]". The German Gynaecology Society "[...] has observed negligence in its application and therefore requests for its manufacture and application to be banned in the interests of preserving the health of the German woman." [5]. This determination proceeded a vote of the Berlin Medical Society. The Berlin-based gynaecologist Gesenius, who was adamantly in favour of a ban on intrauterine pessaries, particularly the Gräfenberg ring, played a considerable role for the vote by means of his talk before this Society in May 1935 and its publication in Zentralblatt für Gynäkologie [9].

Even Gräfenberg himself no longer officially applied rings any more after his forced emigration to the USA by the National Socialists in 1940 [16,23]. After the problem of contraception with intrauterine rings was discussed positively at an international conference in 1962 in New York, the Gräfenberg ring and its modifications made from polyethylene and nylon experienced a renaissance, and the method was revived [4,22]. Gräfenberg, whose death in New York in October 1957 was largely ignored, was no longer part of this development [15].

In 1964, Thomas and Roesler reported two women who had had rings in utero for 13 and 20 years respectively, and who had experienced no significant discomfort. In both cases, the "metallic foreign body" was not able to be removed from the uterus through curettage, with a hysterectomy being decided upon in both cases (1963/4). The histological examination of the uterus resulted in an inconspicuous histology [22]. One year later in his piece "On the resurgence of the Gräfenberg ring in the United States", Gesenius revised his scathing criticism of the Gräfenberg ring from 1935, and actually again critically discussed a 55-yearold patient with a Gräfenberg partially imbedded in the myometrium after 15 years, which was removed along with the uterus during a prolapse operation [10].

Our case study can be explained by the clear resurgence in the use of intrauterine pregnancy prevention systems in Europe and North America in the late 1950s/early 1960s [17]. Alongside this medical history aspect, the case shows that intrauterine foreign bodies are among the rare differential diagnoses in the case of a conspicuous endometrial sonogram finding.

\section{Conflict of Interest}

None.

\section{References}

1 Chen CH, Liang HS, Chiu LH et al. Broken Gräfenberg ring incarcerated in para-ureteral space: a rare case of retained IUD accompanied pregnancy. Eur J Obstet Gynecol Reprod Biol 2013; 169: 412-413

2 David M. Ernst Gräfenberg (1881-1957). In: David M, Ebert AD, Hrsg. Berühmte Frauenärzte in Berlin. Frankfurt a. M.: Mabuse; 2007: 151160

3 David M, Ebert AD. Der Gynäkologe Ernst Gräfenberg - (missverstandener) Entdecker des G-Punktes. Geburtsh Frauenheilk 2012; 72: 795797

4 Davis HJ. Intrauterine devices for contraception. The IUD. Baltimore: Williams \& Wilkins Co.; 1971

5 Deutsche Gesellschaft für Gynäkologie. Resolution der Deutschen Gesellschaft für Gynäkologie zur Anwendung intrauteriner Schutzmittel. 24. Tagung der DGG. Archiv Gynäkol 1936; 161: 23

6 Döring GK. Empfängnisverhütung. Ein Leitfaden für Studenten und Ärzte. Stuttgart, New York: Thieme; 1990: 34-37

7 Farghaly SA, Mathie JG. Retained Grafenberg ring for 39 years discovered during abdominal hysterectomy. Aust N Z J Obstet Gynaecol 1980; 20: 248-250

8 Fraenkel L. Schlusswort. Archiv Gynäkol 1931; 144: 379-383

9 Gesenius H. Die Gefährlichkeit der Intrauterinpessare. Zentralbl Gynacol 1935; 37: 2168-2178

10 Gesenius H. Zur Rehabilitation des Gräfenberg-Ringes in den Vereinigten Staaten. Geburtsh Frauenheilk 1965; 25: 38-43

11 Gräfenberg E. Silk als Antikonzipienz. Vorträge und Verhandlungen des Ärztekurses vom 28. bis 30. Dezember 1928 „Geburtenregelung“. Bendix E, Hrsg. im Auftrag des Komitees für Geburtenregelung. Berlin: Selbstverlag Dr. Bendix; 1929: 50-64

12 Heng GT, Kuan BB. Retained Graefenberg ring intrauterine device mimicking fractured Lippes loop in-utero. Med J Malaysia 1985; 40: 44-45

13 Jessen $D A$, Lane RE, Green RR. Intrauterine foreign body. A clinical and histopathological study on the use of the Graefenberg ring. Am J Obstet Gynecol 1963; 85: 1023-1032

14 Ludwig H. Ernst Gräfenberg (1881-1957) in der Gynäkologie seiner Zeit. In: Semm K, Schirren C, Hrsg. Die intrauterine Kontrazeption. Internationales IUD-Symposium Helsinki/Kiel. Fortschritte der Fertilitätsforschung 10. Berlin: Grosse-Verlag; 1981

15 N.N. Nachruf Dr. Ernst Graefenberg. New York: Aufbau; 8. Nov. 1957

16 Rothe K. Methoden der Empfängnisverhütung. Jena: Fischer; 1973

17 Rutherford AM. The Graefenberg ring. New Z Med J 1961; 60: 413-415

18 Saigal MD. Some observations on the complications following the use of Graefenberg ring. J Indian M A 1962; 39: 192-194

19 Semm K, Giese KP. Ernst Graefenberg, das Leben und Werk des Kieler Facharztes. Zum 100. Geburtstag am 26. September 1981. Geburtsh Frauenheilk 1981; 41: 444-448

20 Gräfenberg E. An intrauterine contraceptive Method. In: Sanger M Stone HM, eds. The Practice of Contraception: an international Symposium and Survey. 1931. Zit. in: Speert H. Obstetric \& Gynecologic Milestones Illustrated. New York, London: Parthenon Publishing Group; 1996: 653-658

21 Tatum HJ. Intrauterine contraception. Am J Obstet Gynecol 1972; 112 : $1000-1023$

22 Thomas C, Roesler E. Beobachtungen über langzeitig applizierte Gräfenberg-Ringe. Geburtsh Frauenheilk 1964; 24: 601-606

23 Thomsen RJ. An Atlas of intrauterine Contraception. New York: Hemisphere Publishing Corporation; 1982

24 Wagner H, Beller FK, Bröcker W. Untersuchungen über die kontrazeptive Wirkung des Gräfenberg-Ringes. Eine historische Reminiszenz. Geburtsh Frauenheilk 1977; 37: 124-128 